HSS V.2 (2016)

DOI: $10.1515 /$ hssr -2016-0013

\title{
Mainstream Media Discourse! Or the Divine Word of the Postmodern?
}

Yasser Rhimi*

University of Tunis, Tunisia

\begin{abstract}
This paper calls into question the growing tendency of quasi-absolutism within postmodern mainstream media discourse under the guise of objectivity. The tendency's major aim is to ascribe more believability to its discourse by re-presenting that which it covers as the vehicle of objective truth to the mainstream audience. Two interweaving discourses have marked such objectivity: one in the form of indoctrinating and omnipresent narratives, which via effective propaganda become tantamount to ritualism, the other epitomised in the nostalgia for rationalisation, already inherent in western positivist thought through the exponential increase of quasiempiricism (e.g. investigative reporting or speculative statistics). Accordingly, what the media cover exists. What they do not remains in the order of myth. The article starts by rethinking objectivity within modern western academia, a discourse whose objectivity is already flawed from within. Then, with respect to human experience and media coverage, the paper concludes by raising the question of postmodern mainstream media's substitution of religious quasi-absolutist narratives, be they secular or nonsecular. Subjectivity thus emerges as the ultimate ground upon which our being may be legitimate.
\end{abstract}

Keywords

Ex-act, Subjective-embodiment, Propaganda, Ritualism, Rationalisation, Quasi-absolutism, Transcendence, (de)Legitimation

Institut Supérieur des Etudes Appliquées en Humanités de Tunis, Rue Florian, Borj Zouara, Bab Saadoun, Tunis, Tunisia ; yasser.rhimi83@gmail.com 


\section{Introduction: The Metaphysics of Objectivity}

\section{a.Objectivity Re-considered}

Before I reconsider the roots of what it means to be objective in modern western academia, and spot some of its obvious marks in mainstream media discourse, ${ }^{1}$ terms like MSM, PMD and SHE will stand respectively for: mainstream media discourse, postmodern media discourse and subjective human experience. In point of fact, concepts like objectivity resist definition, or rather, an $e x-a c t^{2}$ or transcendental definition. For this reason, objectivity has never been thoroughly devoid of subjectivity. To approach objectivity with objectivity, therefore, the academic researcher has to place him/herself outside of the system within which what it is to be objective first emanated. This should occur without even giving the slightest impression of being non-objective or subjective: a statement no decent scholar can easily claim. Still, to make sense of our finite and ostensibly chaotic human being in a world where much of it is as yet bewildering as its plain observable truth, intellectuals, from philosophers to scientists and truth-seekers, have had to opt for a rationale of thinking whereby they could measure if such a claim, statement, theory or hypothesis could be judged as true or false; or if our reality of being is worth being taken as authentic or deceitful. Such logic of reasoning has admittedly had its roots in antiquity and it has been increasingly deepseated through the development of the modern human enterprise. Myriad definitions and interpretations have, indeed, been attributed to objectivity, each being oriented to a specific tradition or school of thought which favours, either explicitly or implicitly, certain definitions of objectivity over others.

As it would be academically partial to take such an historically- as well as epistemologically-ingrained concept for granted, I find it more reasonable, if not more objective, to first introduce it with respect to its original implications in the scientific/empirical history and philosophy of academic research in the west. Next, I will undertake the task of testing our current PMD against certain positivist as well as speculative traits of objectivity. My aim is to challenge the claim that global news agencies could ever be neutral while increasingly paradoxically acting as rational and indoctrinating at once. 
Staring with a preliminary, though relatively comprehensive, elucidation of objectivity provided by the Oxford Advanced Learner's Dictionary (New $8^{\text {th }}$ edition), the "objective" is that which is "not influenced by personal feelings or opinions; considering only facts;" and in philosophy, still according to the same source, an objective reality is that which exists "outside the mind; based on facts that can be proved." Within this framework, three major schools of thought have flourished, each according to its distinct initial reception and later conception of what it is to be objective: the positivist, the interpretive and the critical. Respectively, the first school can generally be associated with physical or natural sciences (NS), whereas, the second and the third with social sciences (SS) and humanities. The latter schools are qualitative or semi-qualitative. Even if, at times, they may approach the scientific with non-scientific data, each depending on the discipline's priorities (e.g. sociology, linguistics and cultural studies), their outcomes remain "pseudo-scientific." (Popper, 1962: 33). As for the former, namely NS, they have been marked by a scientific method that is almost entirely based on empirical observation.

Historically, the latter has granted NS a higher status in modern academia, since it is much closer to the factual and material life rather than the fictitious and metaphysical one. In this regard,

Put simply, positive research strives for an objective, clinical means of studying the subject matter. It tends to be dominated by quantitative techniques, using statistical analysis of data to study the underlying "at a distance". This allows for objectivity while ensuring external validity as the experiment can theoretically be re-performed with similar results ... On the other hand, interpretive and critical research styles tend to be more qualitative. As such, there is a higher degree of subjectivity. The methodology recognises the fact that there are important social and cultural variables that impact on the subject matter and that these interconnections cannot be ignored. Validity is driven, not by a clinical approach to the study, but by a methodology based on documenting the findings in detail to provide a thorough account (Warren, 2012: 1-6).

Therefore, between the purely positive/empirical tradition (which binds itself by a limited number of variables), the pseudo-positive (which broadens the possibility of factors) and the anti-positive traditions (which 
make all variables relatively context-bound), the debate over which an objective approach or definition can be the most appropriate to be embraced by scholars has remained inconclusive and discipline-specific.

Modern Western academia has remained vehemently faithful to scientific traditions and methods long developed by philosophers of science, such as the French René Descartes (deductivism) and most notably the English Sir Francis Bacon (inductivism). From around mid$17^{\text {th }}$ century to date, modern academic research has preserved its "bias in favour of quantitative, or positive, research" despite all "the inherent limitations of the [positive/scientific] methodology" (Warren, 2012: 2). Furthermore, with the French philosopher or the eminent founder of the positivist tradition in academic research Auguste Comte's "law of the three stages" of human history, where he considered that "the human mind and by extension the cultural institutions that result from it follow a strict progression from a "theological" view of things, to the "metaphysical", and finally to the "scientific," 3 the positivist or quantitative method has acquired a quasi-absolutist character in the name of science to judge what is objective about reality and the methodological means to realise it. In this vein, the degree of empirical data with which academic research might or might not be invested has become the positivist of reference against which an objective analysis can be measured and upon which NS, SS and humanities differed. In doing so, be it positivist or anti-positivist, each academic tradition has come a long way to lay the foundations for its proper legitimate and certified truth, the implications of which would be a whole process of selection or de-selection, emphasizing or de-emphasizing and commending or rebuking different forms of scholarly knowledge.

Their academic touchstone would, therefore, be their distinct, at times, unique, model of positivist objectivity. Ironically, the historical-scientific mistake some rigid positivist tendencies in the NS did by blindly embracing Comte's scientific absolutism have already enclosed them within rather than freed them from a quasi-theological tradition they recklessly attempted to escape. The difference, this time, is that their objectivity worked under a new guise of the scientific: the apparently neutral. In 1957, analysing this quasi-absolutist scientism, the German philosopher of science Karl Popper astutely observed that scientific hypotheses, "must be tested, they must be submitted to the method of selection by elimination" (The Poverty of 
Historicism 134). "This, in outline," Popper proceeds, "is the method of all sciences which are backed by experience" (ibid.). Accordingly, at the heart of empirical/scientific research resides "test[ability]", "selection by elimination" and "experience", without which the two former ones are invalid. This means that, even if it is hypothetically tempting for a researcher, without tested or demonstrated empirical data, the theory at stake is untenable. On these grounds, Popper posited that an academic research is "empirical or scientific only if it is capable of being tested by experience"; hence often liable to be proven wrong no sooner do the appropriate conditions of its theoretical and empirical testability agree to its falsification (The Logic of Scientific Discovery 18).

Popper's demarcation of scientific discourse by falsifiability should not in any way lead us to automatically reject the speculations made by scientific investigation and research, nor even reduce them to mere falsifications. On the contrary, while he distinguished between the empirical scientific method and what he calls pseudo-science from the SS (e.g. astrology and psychology) and superstition, he made one of the most significant departures in the history of science and philosophy from radical positivists' classical understanding of empirical science as beyond observable absolute truth. In short, based on Popper's arguments, every scientific theory is falsifiable and thus refutable, and workable only under certain theoretical and material circumstances. Such a dictum, I would underscore, renders both scientific method and its hypotheses more coherent with and less belligerent to the interpretive and the critical perspectives of academic research, since it puts all scientific research "under erasure." The latter, from an interpretive Derridean standpoint, therefore would entail that scientific premises are "inadequate" since liable to testability by other contradictory theories, yet "necessary" as they may well function within relatively limited contexts; ${ }^{4}$ hence the bracketing as well as relativisation of all ostensibly absolute scientific theories, even of those based on empiricism.

Today, logical reasoning and rational thinking as quality measures for an excellent, good or mediocre academic product have continued to have their strong hold in many areas including journalism, to some extent, in the humanities, e.g., academic essays and dissertations. Still, the interpretive and the critical traditions, which have long suffered from a relatively 
exclusive hierarchy under the label of subjectivity and anti-positive thinking, followed corrective tendencies of the rigid positivist tradition. These revisions may best be recognised in the interpretive works of the German sociologist Max Weber, who re-focalised positivist sociology on a deeper "understanding [of] subjective experience, as opposed to a rigid adherence to facts and observation," much like the Frankfurt School's Critical Theorists, such as Theodor Adorno, Max Horkheimer and Herber Marcuse, whose interdisciplinary integration of SS and the humanities could "expose flaws that might invalidate"(Cranford, 2015) the naturalised or absolutist conclusions concocted by the different social, economic and political hegemonic forces. Along this line, my argument goes on as follows: if "[t]he goal of a scientific [positive] discipline was therefore necessarily narrow: to establish the laws that explain natural phenomena within its own field, and thus to account for only a small part of reality,"(Moran, 2002: 6) - the academic attitude which has led to the obvious "superiority of the sciences over the humanities disciplines"(Moran, 2002: 8) - then the interpretive and the critical traditions' research targets in academia have been, first, to question those positively-constructed laws; and second, to thrive in endowing the idealised objective reality with what it lacks: our SHE.

It is worth noting that the previously advanced contextualization of the scientific implications of what it is objective in the history as well as philosophy of the academia is meant to bring the logic of this article to our next analytical attempt at examining the dialectical as well as metaphysical nature of objectivity. To respond to such queries as what objectivity and whose objectivity, an academic scholar should either remain blindly faithful to his/her discipline's virtually rigid delimitations, or take one's academic courage, as it were, in both mind and heart and attempt to gain some promising analytic insight. Being completely aware of the extreme delicacy of the issue at stake, namely objectivity, I would like to clarify that the present paper's prime interest is to re-consider the consensual definition of what it is to be objective in the light of our current PMD, as its title indicates. It undertakes the task of questioning rather than confirming, inspecting instead of proving that our current PMD has largely substituted the traditional religious discourse; and that, for example, the mass-media, news agents, and the audience have respectively symbolically superseded 
the house of God, religious preachers and religious believers. By religious, I mean both the secular and the non-secular tendencies voiced in our current global media discourse. Finally, to uphold a constant flow of one's queries, my examination will waver between widely acclaimed investigative reports/observations, media theorists' pertinent as well as insightful remarks and hypotheses and my analytical speculations already introduced in the abstract.

\section{b. Objectivity: Dialectics}

Back to $O A L D$ 's relatively inclusive definition of objectivity, as it has generally been viewed throughout history, I would like to underscore the dialectical nature of the concept per-se in contrast to subjectivity. To consider only "facts" while preventing one's own personal feelings and opinions from interfering in the act of examining an object or a concept, i.e. to remain "unbiased" and "impartial", and yet "prove" it right or wrong, would virtually demand that the observer/perceiver detaches one's consciousness from the body, which is the source of all reactionary attitudes from fears, desires and value judgments. The aim, in this sense, is a highly accurate and exact apprehension of either an object being perceived or a conceptual idea being conceived. Therefore, to be exact in one's objective aim at objectivity is to act outside the frame of our human subjectivity, namely our human experience, which necessarily entails error in one way or another. Ipso facto, to be purely objective is to negate what it is to be human. If such a negation is possible, the human is not human any longer. One has to simply become a machine; and yet an automaton is by definition the product of a pre-determined human intelligence and design. On this basis, how far is pure objectivity realisable outside of its preexisting human constructedness? In a general attempt to reach objectivity, truth seekers from scientists and philosophers, to academic researchers and all the different kinds of investigators, would take their distinct and, at times, overlapping objective measures.

As a rule, the method employed should keep and demonstrate a great space of detachment as human subjects from the object of objectivity, be it mental or experimental. I would call such an endeavour at ultimate exactitude an ex-act (see note 1). The latter would require a pre-condition of negation of our involvement as mental or material bodies through which 
our SHE is being conducted. In phenomenological terms, particularly, in the German Edmund Husserl's tradition, what I call ex-act would be a purely cognitive (intentional) process of defining the "essence" of objective reality "irrespective of its causal origin." 5 The outcome of this ex-act of pure consciousness would be an objectivity that is as independent and transcendental from our bodies' materiality. It is an essentialist attempt at objective reality which, though being the product of our SHE, ultimately regulates and even suppresses its own subjectivity (human constitution). By contrast, neither Popper's falsifiability as a demarcation of empirical science, nor our human body experience of the empirical research being conducted by the academic scholar, would agree to a relatively absolute objective reality that is nearly thoroughly autonomous from our SHE. As mentioned earlier, for Popper, scientific theories have to be tested through observation, i.e. grounded on material experience certainly conducted by humans, which in turn rooted scientific empiricism in subjectivity.

Accordingly, if exact objectivity already pre-supposes an ex-act of perception of objectivity as a token of the perceiver or examiner, more importantly, in the academia, then such a process would suggest that the subjective perceiver has to be almost completely detached from the system within which objective reality exists. In other words, the objective perceiver of objective reality has to stand outside objectivity's system of operation or domain of influence by embracing or turning oneself into a Punctum Archimedis, that is "a true Archimedean point - a god's-eye view - of ourselves and our world" (Shermer, 2007). Yet, as I mentioned earlier, this cannot be achieved except by either a thorough negation of the human body, or by operating from a quasi-divine ground outside of the system being examined. In both cases, we end up abrogating our human subjectivity, which is the product of its inseparable, different, yet not necessarily opposite, objectivity. Henceforth, on the one hand, we know that objectivity sensu stricto is a social as well as academic construct. On the other hand, we cling to it to make sense of our own humanness as subjective entities in an apparently chaotic human condition.

The response to such philosophical queries were also already criticized and answered by the French existentialist phenomenologist Maurice Merleau-Ponty. For him, all understanding of the objective world's phenomena, whether including or not including scientific empirical 
observation of science, are already experienced by the human body (the centre of all acts of consciousness and behaviour with all their materiality and cognition). For this reason, in denouncing scientific absolutism, he followed in the footsteps of his sphere of influence, namely Husserl and Heidegger, to state in his Phenomenology of Perception (1945):

I cannot shut myself up within the realm of science. All my knowledge of the world, even my scientific knowledge, is gained from my own particular point of view, or from some experience of the world without which the symbols of science would be meaningless. The whole universe of science is built upon the world as directly experienced, and if we want to subject science itself to rigorous scrutiny and arrive at a precise assessment of its meaning and scope, we must begin by reawakening the basic experience of the world of which science is the second-order expression. (viii)

Merleau-Ponty's phenomenological grasp of human observation of facts or phenomena postulates that in the act of human observation there is no experience outside the body (subjectivity). Otherwise, this would be a "complete reduction" from the part of what he calls "absolute mind," be it philosophical or empirical, which for him, does not exist. By contrast, Merleau-Ponty proceeds, as "we are in the world ... our reflections are carried out in the temporal flux on to which we are trying to seize" objective reality and this, indeed, already results in the debunking of any "thought" which purports it "embraces all our thought" (xiii). Therefore, all kinds of scientific (cognitive or empirical) or non-scientific (interpretive or critical) observations, are already, indeed, inextricably embedded in our human act of perception of the objective world, which is always already, I would claim, subjectively-embodied.

\section{c. Objectivity: Metaphysics}

Those who claim or pretend that they are seekers of objective truth by academic or non-academic ex-acts of investigation hide the real aim behind their quest for ultimate presence (of transcendental truth) over absence. Absence here is that of thoroughgoing meaning, i.e. that "self-evident truth [ironically] gained through introspection," (Husserl, 2008: 183-197) they incessantly project onto our SHE. Presence, which is noted in their quest for objectivity, marks the absence of our quest for a true meaning of 
ourselves and the world surrounding us. In so doing, we are prone to forget that in its incessant desire for transcendental or quasi-divine autonomy, objectivity exhibits its real exclusive character towards its being the product of our human subjectivity, be it academic or social; and hence its hostility towards its difference to itself, to its own subjectivity. It is to such exclusive tradition that positivist thinking has subscribed. By contrast, both the interpretive and the critical traditions of thought have generally engaged with the subjective embodiment of objectivity. So is it and always will be so long as what constitutes us as social human beings is, by definition, our immersion in desire, fear and social value. If the quest for objective truth is already concealed by our incessant desire for an omnipresent meaning and our quest for the latter likewise stands upon a mercurial ground of subjectivity, then the whole notion of objectivity here becomes suggestive of a somewhat symbolic violation.

This symbolic violation is of the order of symbolic treason which stems from its reversal structuration of our SHE's course of action by framing, suppressing or finally negating it. Hardly do objective reality as a concept in a work of research or any given culture reach its extreme limits of impartiality and independence, taking for granted that they have been produced by impartial scholars, as it were, when these objective concepts begin to appear so transcendental and god-like in their transcendence of our subjective human reality. Once this occurs, what it is to be human, i.e., our SHE becomes that mere abject reality that is thoroughly liable to a quasi-sacred, quasi-divine construction of which we tend to be forgetful that we once created to now be framed and enslaved by its new laws of governance. Such quasi-absolute objectivity is perpetrated in the name of positive and rational thinking, as it were. Meanwhile, between its elevatedness to a quasi-divine status and its empirical veracity on the ground of subjectivity, objectivity dwells in perpetual denial of its difference, i.e. of its own subjectivity.

\section{MSM: Two Quasi-Absolutist Tendencies}

In this section, I shall call the postmodern media institutions in question with respect to their reproduction of objectivity as a quasi-absolutist discourse to a growingly passive audience. To embark on such an intriguing task, one should first observe our present-day media's status quo, 
describe its general tendencies and provide appropriate examples whereby I could support my queries. Second, with respect to my foregoing analytical study of objectivity (i.e. its aspects of quasi-autonomy, negation and subjective embodiment), I shall test our current PMD's objectivity with the aim of spotting major criteria of any quasi-absolutist discourse, be it secular (positivism) or non-secular, e.g. ritualism, indoctrination and (blind) devotion.

As a matter of fact, in the Age of Information, or "The Implosion of Meaning in the Media" (79-80), as the French cultural theorist Jean Baudrillard labeled it, our exponential access to information or rather "information overload" via the mass media has turned us into symbolically-illiterate individuals. With all their daily "bludgeon[ing]" (2021) in the form of news, entertainment or advertising, to draw on the political scientist Noam Chomsky's terms, ritualistic in both form and character, propagandistic media have achieved "spectacular" (53) results in targeting the postmodern social individual's "mediasphere"'. The aim is to transform our present-day world of being into a virtually unreal one. Meanwhile, their mediatised world of print, screen and digital messages have grown intensely more real. What the media covers from events and phenomena is factual and objective, and thus is believed to exist. What it does not is either of the fabricated or the superstitious. In other words, it is in the order of the metaphysical. For example, thanks to propagandistic media (print, screen and electronic) we all believe in the genocides committed by Hitler against the Jews during the Second World War.

However, when history repeats itself with difference with Zionist Jews themselves who have been perpetrating war crimes against the Palestinians (from both the Christian and Muslim faith), the western world remains silent out of either ignorance (though at times surprised and even shocked to know about the reality on the ground thanks to alternative media outlets or field visits), or due to political complicity. The killings of thousands of children, women and elders of Palestinians, along with the use of internationally forbidden arms (e.g., phosphorous bombs) against them by the Israeli forces, were condemned by human rights organisations worldwide. One of the latter's most important organisations, Amnesty International, acknowledged in 2014, the "'growing evidence of war crimes" 7 against the Palestinians in Gaza and "called for a total arms 
embargo on all parties to the conflict." As Gaza has then already been under siege by Israel for about 8 years, it was clear that those atrocities were committed by the Israeli state. In a context fraught with the violations of the international law and the silence of the international community, the United States (US: the world's most powerful nation and the one which has pledged ethical responsibility of the peace process to solve the two nations' bloody conflict) kept on "send[ing] at least $\$ 3.1$ billion in military aid grants to Israel every year, more than the amount given to all the rest of the world combined" (Erickson, 2015).

As Barbara Erickson, a former East Bay newspaper journalist, editor and journalism teacher at UC-Berkeley, blatantly divulges in her article entitled "How The NY Times Hides the Scandal of US-Israeli War Crimes":

The subject of military aid to Israel demands a fuller treatment in the Times. Readers should know the actual cost to U.S. taxpayers; they should be told of ethical concerns raised by organizations and officials; they are entitled to know more about the lethal effects of Israel's weaponry; they should find Times analysts willing to discuss the contrast between congressional largess for Israel and the efforts to cut domestic programs. It is not too much to say that US military aid to Israel is scandalous in light of the devastating effects it has had on innocent Palestinians and also on Americans deprived of basic needs. The failure of the Times to address the issue also amounts to scandal, making it fully complicit in this sordid affair (Erickson, 2015).

Interestingly, as a rule, either the Western MSM coverage of such unethical onslaughts against the unarmed Palestinian civilians intends to ignore the opposite version of truth being reported, or the real aggressors and killers on the ground are portrayed as victims retaliating with their highly sophisticated weaponry to an overpopulated area of unarmed civilians in revenge of daily aggressions against them. Even from within the Jewish community itself, this attitude of dehumanisation of the Palestinians is undeniably unacceptable ${ }^{8}$.

One way to explain this bias is what a former Associated Press reporter of global conflicts and, particularly, of the Israeli war on Gaza (a district of Palestine), is that [t]he Western press has become less an observer of this conflict than an actor in it, a role with consequences for the millions of 
people trying to comprehend current events, including policymakers who depend on journalistic accounts" (Friedman, 2014).

Psychologically - the reporter's confession goes on, "[j]ournalistic decisions are made by people who exist in a particular social milieu, one which, like most social groups, involves a certain uniformity of attitude, behavior, and even dress" (Friedman, 2014). Such humanly affective, if not intentionally, opportunistic fallacy on the part of the reporter with local residents for each or both of the two camps would automatically add a lot more pressure on investigative journalism and its sanctified, as it were, quest for objective reality and would necessarily influence its initially objective pursuit of objective reporting. Another reason is perhaps the one given by Hasan Abu Nimah, the former permanent representative of Jordan at the United Nations, which is the "prestige" of a second-term office at the UN, which though "alarmingly revealing," lured Mr. Ban KiMoon "even if that price is paid in innocent people's blood" (Nimah, 2009). Shockingly enough, provided that there has been thorough objective reporting of such international conflict as the Israeli-Palestinian one, how could one explain UN Secretary General Ban-Ki Moon's publication and sending to "the Security Council only a 27-page summary of the 184-page document submitted to him by a board of inquiry led by a former head of Amnesty International'?

Surprisingly still, how could he reject "a key recommendation that there be a full independent investigation into numerous killings and injuries caused to UN personnel and Palestinian civilians during the Israeli assault" from 27 December 2008 to 18 January 2009 (Nimah, 2009)? Other examples of genocides amongst the weak of the world are the Rwandan Genocide in 1994 and the Srebrenica Massacres in 1995. During the former "hundreds of thousands of Rwandans [app. 800,000] were dead and many more displaced from their homes... 2 million more refugees [to the neighbouring Uganda] from Rwanda, exacerbating what had already become a full-blown humanitarian crisis" . What about the response of the International Community via-à-vis Rwandans were being slaughtered by their own people's militias over 3 months? The answer is that most of the world's common people, not necessarily intellectuals or politicians, who were a significant as a force to pressurise on their governments to intervene and maintain peace under the United Nations' flag, were ignorant, since 
such criminal atrocities were not mediatised or televised. In this context, "the international community largely remained on the sidelines during the Rwandan genocide"10. One of its prominent witnesses Roméo Dallaire11 clearly states that,

The news media - both domestic and international - played a crucial role in the 1994 Rwanda genocide. From my vantage point as commander of the United Nations Assistance Mission for Rwanda (UNAMIR), I was able to watch the strange dichotomy of local media, on one side, fuelling the killing while international media, on the other side, virtually ignored or misunderstood what was happening. The local media, particularly the extremist radio station Radio-Télévision Libre des Milles Collines (RTLM), were literally part of the genocide. The genocidaires used the media like a weapon. The haunting image of killers with a machete in one hand and a radio in the other never leaves you. The international media initially affected events by their absence. A tree was falling in the forest and no one was there to hear it. Only those of us in Rwanda, it seemed, could hear the sound, because the international media were not there in any appreciable numbers at the outset. (12)

That the local media were directly involved in escalating the fuelling of the massacres in Rwanda, one could understand, though not justify it, under the pretext of the blindness of ethnic bias.

By contrast, that the international media, reluctantly or not, were not present to report and thus prevent the onslaught against the unarmed or even armed civilians in Rwanda it is legally unacceptable of them and their silence makes them even ethically tacitly responsible for gratuitous bloodshed. Equally, during the Srebrenica Massacres, "the site of the worst atrocities in Europe" since 1945, the international community failed to prevent the slaughters against the Muslim ethnicity, where "over 8,000 Bosnian Muslim or Bosniak men and boys were killed in Srebrenica in July, 1995” (Erin Murphy 4). Philip Corwin, the then

highest ranking United Nations civilian official in BosniaHerzegovina...decried the distortions of the international press in their reporting, not only on that event, but on the wars in Yugoslavia (1992-95) in general... [and] expressed the wish that there could have been, and must be, 
some balance in telling the story of what actually happened in Srebrenica and in all of former Yugoslavia, if we are to learn from our experience. (7)

Whether Corwin's testimony to the international press' predisposed reporting of the war in Yugoslavia was in favour or disfavour of one of the two camps (the Serbs and their enemies, the Muslim Bosniak), it is not of any interest here. What must be taken into account, though, is the mass media "distortions" of the Balkan conflict. As I mentioned earlier, the media's quasi-absolutism works either by way of dereliction to report such conflicting events, or by way of distortion and the spread of disinformation in the form of factual news. To cover news here has become even more aporetic, which begs the following question: When reporters report local or global events on the ground, do they cover (i.e. give an account of) or cover (i.e. conceal/mask out of dishonesty) them?

The majority of social individuals are diverted from the events that really take place on the ground using the mass media as effective, yet calculated, tools for such a hegemonic goal. Undoubtedly, hegemonic powers both local and global, in whose interests this luring aim of keeping on a string over the masses, may be rewarding, may range from, most notably, business tycoons and politicians to traditional intellectuals and the naive masses themselves, who in uncritically subscribing to the former's hidden or announced agendas, are being kept as "the bewildered herd," to draw once again on Chomsky, "from paying attention to what's really going on around them" and thus kept "diverted and controlled" (Media Control 44); and such is the core of effective mass media propaganda: the more they parade, the more they succeed to shroud. In point of fact, I shall draw on a number of techniques as I go along with my present analysis. Since the post-war era, the MSM discourse has increasingly acquired quasi-absolutist features, which I would not venture to describe as transcendental or godlike in their appeal to the masses. On no account should the MSM be judged as useless or that alternative media outlets are automatically the best way to counter the former's hegemony or attempt "to impose forms of mental slavery," as Chomsky would formulate it, be they visible or not, over the citizens' free minds, not even under such exaggerated circumstances as the as-yet-infamous war on the as-yet-amorphous ghoul named terror, waging it against some while unconditionally nurturing it with others (allies), "so they 
HSS, vol. V, no. 2 (2016): 40-73

would accept a framework of indoctrination and wouldn't raise any questions," (Power Systems 101).

The major case I would like to make is rather to debunk those quasiabsolutist tendencies which emanate from MSM or even alternative media excessively mired in arbitrary neo-liberal forces ("free market" and "big business"), which can be traced back to the first half of the $19^{\text {th }}$ century Europe. Even the ideal maxim elevating the press to a quasi-divine status, first, as a "fourth estate [or power]" of the modern, western, liberal democratic nations protective of democracy (Hassan, 2004: 133) and, second, as an autonomous, omnipresent, transcendental and god-like body in their re-presentation of reality should incessantly be kept under civil society's and academics' critical scrutiny. These two factors have to date crucially disfigured global news agencies' original enterprise of invigilating the governments, on the one hand, and broadening the citizens' scope of knowledge, and thus liberating them from those prescribed by hegemonic powers, on the other hand, the stake in which the mass media largely failed (Hassan, 2004: 133). In point of fact, right from their early developments during the 1840s, the former determinant (neoliberal forces) behind our current mass media's quasi-absolutism recognised

- the close links they forged between news and the global financial market;

- the 'journalism of information' they developed, with its standardised formats and routine devices for guaranteeing facticity and credibility; and

- the way in which they catered both to national, often propagandistic, interests, and to international, often market-oriented interests (David Machin and Theo Van Leeuwen 7-8).

Such lucrative tendency has, indeed, exponentially carved the setting of global news agencies' agendas ever since. For example, if in 1981, "The big four [news agencies]: United Press International, Associated Press, Reuters and Agence France Presse - provide[d] over 90 per cent of foreign news printed by the world's newspapers," the result was that they controlled .... "[t]he news-gathering priorities"12 which were mostly incongruous with those of the developing countries. Within this purview, our current global news agencies still "operate on the principle that 'almost anything that passes as news in print, broadcasting and electronic media is likely to have 
some financial implication for someone' and that the best stories 'move markets" (Machin and Van Leeuwen 8; emphasis mine). Still, the real threat to civil society and, particularly, to the social individual, comes from the inevitable economic-political interests luring news agencies' owners and investors, on the one hand, and the rulers of the state, on the other hand. Tracing the routes of propagandistic media within the U.S. context, eminent political analysts Edward S. Herman and Noam Chomsky came to the conclusion that "money and power are able to filter out the news fit to print, marginalize dissent, and allow the government and dominant private interests to get their messages across to the public" (2).

Mass media's quasi-absolutism's latter factor (quasi-divinity) may be examined in the light of their god-like capacity to miraculously be not only nearly omnipresent in almost all the world's numerous hotspots (social, economic, or political) being on their priorities list but, above all, to grant life, to some events while almost officially denying it to others. In a complex world of overt and covert superpowers steadily contending over which one or allies could harness our present times' most advanced fetish, namely the mass media and the mass communications, nothing occurs unpremeditatedly. The so-called objective reality is intricately concocted to be massively marketed for and by its own consumers. What we call, for example, "journalistic [or media] objectivity", which "can refer to fairness, disinterestedness, factuality, and nonpartisanship, but most often encompasses all of these qualities"13 should constantly be called into question; for few who would dare discredit the source of the events, without which their understanding of the world and keep track of information would be impossible. Therefore, I would like to repeat that as what the media cover/report is extant while what they do not is extinct or dead, the mass media have been elevated to a quasi-autonomous, quasi-divine status upon which the present as well as future being of modern governments and the millions of the audiences is predicated. As a consequence, global as well as local processes of selection (privileging) and deselection (rejection/ dereliction) of what to broadcast and what not to broadcast have continued to grant life or death to events behind which the plight or salvation of social individuals or even whole nations fundamentally resided.

In the meantime, while global news agencies continue to circulate their objective, as it were, narratives, through make-believe, by "attributing their 
information to a spokesman, the press, or other sources ... so as to avoid making judgments,"14 Herman and Chomsky's "propaganda model, or set of news "filters," thrives to show how, for political as well as financial gains, global news agencies may conspire to frame people's consent to issues they are meant to be thoroughly ignorant about. The news filtering process "occurs so naturally that media news people, frequently operating with complete integrity and goodwill, are able to convince themselves that they choose and interpret the news 'objectively' and on the basis of professional news values" (Herman and Chomsky 2; emphasis mine). An excellent example of this is the U.S. Pr. Georges W. "Bush administration [which] devoted extraordinary resources and expertise to framing the news coverage before, during and immediately after [Secretary of State Colin] Powell's presentation in an attempt to set the news agenda and advance its case for war" against the menace presented by Pr. Saddam Hussein's weapons of mass destruction (WMD) in Iraq (Shlemon, 2013: 5). Today, after almost 13 years from the run-up to the war in 2003, no single trace has of late corroborated Powell's allegations. In the meantime, the result was that hundreds of thousands of innocent civilians were killed (many of whom were children, women and elders), millions of casualties, violations of the human rights in both Abu Ghraib and Guantanamo Bay prisons, along with the crimes which were according to the international organisations of human rights tantamount to war crimes.

All these war atrocities are yet to be forgotten since as Yahya R. Kamalipour and Nancy Snow state, at that time, "[i]n a world of mediated politics, WMD [did] become in effect weapons of mass distraction in the struggle between the US (upholding world security) and international terrorists (spreading world insecurity)" (63; italics mine). It is because, geostrategically, the real aim was something else: to control Iraq's oil supplies, blockade Iran's westward expansion and certainly secure the state of Israel. Ironically, this may remind us of what I advanced earlier about the mass media's exhibition, on the one hand, and masking, on the other. This leads me to even go further in my claim that, if they are effectively utilised, the mass media may turn out to be the real weapons of mass distraction. Within this "hyperreal" (1-42) human condition, so would Baudrillard maintain, already fraught with simulacra and simulations of reality, the mediated have extravagantly prevailed over the unmediated. The broadcast image, for 
example, has become more real, more objective and more sublime to the mainstream audience than reality itself. In addition, with its being the only technical means available for the viewer/audience to access a reality for his/her interest, the media have succeeded to become the postmodern individual's transcendental gate to objective reality or truth.

In its highly indoctrinating secular or non-secular missionary broadcasting, the media discourse has not only remained widely typical of the western industrialised societies, as did the German critical theorist Herbert Marcuse advance in his One-dimensional Man (1964). Rather, it has massively spread to the non-western industrializing countries. Its "glocal" (global and local) (Robertson, 1995) quasi-divine character has awarded it transcendental powers of spatio-temporal ubiquity. It transgresses human limits (geographical, temporal and biological) to report objective reality in the form of instant breaking news or periodic follow-up stories and yet able to support them with objective evidence; for no news agency would dare put at risk its viewership by discrediting its objectivity or neutrality. In this respect, to ascribe more credibility on its current PMD fraught with paradoxes and hoaxes of the massively-mediatised news information and entertainment of different sorts, global news agencies have had to rationalize their subjective objectivity by paying tribute to the spectacular authority which has brought our whole human experience from darkness to light, namely scientific empiricism. Admittedly, as has been introduced in the first section of my paper, despite its relativity, scientific empiricism has led to the world's techno-scientific revolution and the Information Revolution with all its traditional mass media and the recently advanced New media (the Internet and the Information and Communications Technology [ICT]). For global news agencies, therefore, there was an urgent need to gradually rely on the integration of more fieldwork manifest in investigative journalism/reporting, that is

in-depth explorations of some aspects of reality. This news subgenre shares the same standards of objectivity, accuracy, and fairness or balance with hard news. However, a major difference between hard news and investigative reports is the amount of time journalists can devote to the project. When it comes to hard news, journalists typically work on tight schedules; their time limit (deadline) for the completion of an assignment is often only a few hours 
after they begin it. In contrast, journalists who work on investigative reports have quite a bit more time to do their research, interview their sources, and write their script. Their deadlines can be days or weeks from the time they begin, or even longer. Often, though not always, the investigative reporters seek to uncover corruption or other problems in government or business, and the tone of the report resembles that of a detective story. A few television news series, such as 60 Minutes, Dateline NBC, and 20/20, present this type of material (Turrow, 2009: 56).

It is worth noting that, aside from providing trends and calculated percentages, this new form of journalistic scientism called investigative reporting takes more time in preparing news which may be tested by the reporter's personal experience of the event, issue or conflict on the ground; and this can thus be viewed as mass media's move towards a more scientific/positivist reproduction of objective reality to finally re-present it to the audiences whose interactive share is just to consume and pay for it. Someone like Sheila Coronel, the dean of academic affairs at the Columbia Journalism School, founder of the Stabile Center for Investigative Journalism and also "co-founder and former executive director of the Philippine Center for Investigative Journalism," begs the question: "Is It Really Investigative Reporting's Golden Age?" (Coronel, 2014). Ironically, to both common and critical audience, this should sound positive. And the designation positive is critically intended. For the common (usually passively-consuming) audiences, such positivistic tendency to include verifiable, as it were, data renders news broadcasting more objective, more rational and thus more neutral and factual. This attitude allows for more credibility to the news agents, for their Channel and for their investors by increasing their viewership/TV ratings. If this continues to occur, the common audience will refrain from questioning the plausibility of the Channel's information or the quality of its entertainment's content.

Equally, more numbers or presence on the ground does not necessarily bring about more objectivity in the media coverage. Who manipulate(s) and pay(s) for such investigations/investigators is what matters most. For this reason, only the uncommon (critical or active) audience, is aware of the possibility of questioning, and thus verifying if such scientificallyunderpinned news, for example, is true or false to ultimately concur with corroborating or countering it. And it is in this perspective, especially, with 
HSS, vol. V, no. 2 (2016): 40-73

respect to the rationalisation of society and media indoctrination that, for Marcuse,

Late industrial society has increased rather than reduced the need for parasitical and alienated functions (for the society as a whole, if not for the individual). Advertising, public relations, indoctrination, planned obsolescence are no longer unproductive overhead costs but rather elements of basic production costs. In order to be effective, such production of socially necessary waste requires continuous rationalization - the relentless utilization of advanced techniques and science. (52)

Accordingly, is this a new tendency towards a more rationalised hegemony mediated by the MSM over both the critical and uncritical minds? Is this the new form whereby the postmodern individual may be indoctrinated to react more passively as to, for example, terror states like Israel, or ethnic genocides, such as the Rwandan and the Bosnian ones, while being agreeable to the victimisation of the powerful aggressor and the incrimination of the weak victim?

When the Charlie Hebdo Shooting on 7 January 2015 was internationally acknowledged by 40 world leaders who marched in Paris, France, against terror, it was followed by 2 million people, and the news of the world unconditionally labeled it "terror attack" against not only human lives but modern art and civilisation; ${ }^{15}$ the Chapel Hill Shooting of three Arab-Americans on 10 February 2010, (not to mention Iraq's, Afghanistan's, Burma's and Palestine's plights) just one month after the former incident, was either widely ignored by the press (as it never featured on the world's media sources as an act of terror, not even in the previously mentioned source BBC.com) or banalised, for example, by one of the American prestigious journals, namely The New York Times, a "Suspect's Rage" rather than blatantly condemned as a crime of terror, (Katz, 2015) when the birth of the British Royal Baby Charlotte was spectacularly "Heralded on Official Easel" (Webber and Scobie, 2015), it was covered worldwide by global media agencies and it sparked unprecedented hospitality and joy on social media and even amongst politicians (Ore, 2015). Meanwhile, instantly at her birth, the world was, and is still, coldly bearing witness to the agonizing screams of all the famine-stricken children 
of Central Africa or those of the massacres perpetrated against their peers of the Rohingya (Burma, Myanmar) which have to date been unheard-of, except by few striving human voices (Hussain and Jahanzaib, 2015). If so, then, the French social theorist Guy Debord's anticipating notion of the society of "the spectacle is real" (Debord, 2006: 14). For him, "the spectacle proclaims the predominance of appearances and asserts that all human life, which is to say all social life, is mere appearance... a visible negation of life and as a negation of life that has invented a visual form for itself" (Debord, 2006: 14).

When the so-called Islamic terrorists' "sex atrocities" are intensely covered (and they certainly must be) after having been mentioned in a highly-valued report by the UN; ${ }^{16}$ whereas, French soldiers' rape and sodomy of African boys in Central African Republic went almost totally unnoticed; unless a senior UN aid worker (who was, indeed, suspended for doing so) leaked the documents testifying for "the sexual exploitation of children as young as nine by French troops [which] stationed in the country as part of international peacekeeping efforts," (Laville, 2015) nobody would ever know the slight trace of truth about it. Today, with all due respect to the notable centrality of the mass media to our recent societal developments in a complex world unavoidably governed by dint of the mass communications and the high-tech, mass media forms like "newspapers, magazines, comic books, radio, video games, movies, and especially television present a very different form of socialization," probably negative as to our children and youth, "than any other, because they offer no opportunity for interaction;" and yet "influence on [our] children from a very young age and affects their cognitive and social development" at large (Gonzales-Mena et al., 2010).

The American environmental journalist Bill McKibben firmly contents that, except for few young or adult critical audience, "TV restricts the use of our senses - that's one of the ways it robs us of information" (McKibben, 2002: 189). For this reason, mainstream viewers have indirectly been trained to "use TV as we use tranquillizers - to even things out, to blot our unpleasantness, to dilute confusion, distress, unhappiness, loneless" (198). The French sociologist Pierre Bourdieu warns against the "instrumentalization" (14) of the MSM, particularly its visual type, and draws our attention to the kind of "[s]ymbolic Violence" that is "wielded 
with tacit complicity between its victims [audience] and its agents [the media's], in so far as both remain unconscious of submitting to or wielding it" (17). For him, this can be guaranteed by virtue of mechanisms such as, to name but a few, "invisible censorship" (15), "show and hide" (19) and the "circular circulation of information" (23), whose hidden raison d'etre is to subject the audience to certain reflexive conditions akin in both its form and content to ritualistic behaviour: passive consumption of any kind of material or spiritual mainstream product.

Paradoxically, in the age of ultra scepticism, of "only today, in our postmodern age, allegedly full of irony and lacking all belief," (to use contemporary Slovenian philosopher and social critic Slavoj Žižek's words), our occasionally blind devotion to the MSM is manifest "not in our interior lives, but in our acts themselves, in our social practice - [as] we believe much more than we are aware of" (Žižek, 2012: 88; emphasis mine). Accordingly, on no account should our ritualistic attitudes or "the external ritual which materializes [our] ideology" (Žižek, 2012: 88) towards the MSM be grasped in terms of our advanced intellectualness or any material progress. As a glocally-tidal human condition, it has become characteristic of postmodernity's homogenisation and structuration of social individuals and cultures into programmed herds inexorably embedded in liberalcapitalism's matrix. To this extent, knowing that they have partly or mostly been moulded in the image of certain economic and political hegemonic forces, how far are we prone to rely on news narratives? Does the process of selection and deselection underpinning the quasi-absolute media discourse present us with a new form of produced naturalized myths whose status is tantamount to what the French postmodernist theorist J. F. Lyotard designates as "the grand narratives of speculation and emancipation" (38), the former being on the legitimation of the "scientific discourse", and the latter on humanity's freedom or "emancipation" (35)? One should take into account that "[ $\mathrm{t}]$ he mode of legitimation we are discussing" here is that which "reintroduces narrative as the validity of knowledge" (31).

Further still, what new form of legitimation will the PMD with its newly-suspected absolutist tendency attempt to parade, seeing that its secular (speculative and emancipatory) and non-secular (religious) discourses are already challenged by their postmodern "delegitimation" 
(37) underpinned by information-overload and popular culture? In this respect, is it possible to consider any form of dissident news narrative, ignored or rejected by the MSM narratives, a new form of "little narrative [petit récits]" (60)? Observing our current media agents' constant, usually regular, and on schedule broadcasting (in the form of news or entertainment) which works like a postmodern ritualistic performance of some sort of indoctrination observed by the audiences as well as our permanent attachment, if not addiction, to hearing or watching specific news or entertainment in specific news hours as a blind postmodern devotion of some sort of secular confession, I had to call in question our current PMD's covert, if not overt, attempt to enclose the postmodern critical mind within a new framework of quasi-absolutist hegemonic spheres of knowledge.

\section{Conclusion: In Defence of Subjectivity and/or Humaneness}

This article has been an attempt to question the nature of our current PMD with respect to its recent quasi-absolutist tendency. The focus has chiefly on news narratives/reports. As the narrative genres of entertainment and advertising were not part of the analysis, though mentioned as indispensable to the former chief ones, it could be argued that it has given only one facet of the as-yet-complex reality of the notion of objectivity within MSM. My argument is that MSM discourse takes the form of religious indoctrination through mainly recurring, preaching-like news narratives (not to mention once again entertainment and advertising); on the other hand, it supports its claims and narratives by quasi-empirical investigative reporting. As a scientist who would test his/her own theory by experience, the aim of mass information growingly backed up by investigative reports is certainly to find a new form of legitimacy for the news agencies' PMD in a postmodern context that is highly challenged by the exponential ascent of the New media. It is the kind of legitimation whereby grand narratives prevail over little (dissenting) narratives in society. The major issue at stake in the analysis was in MSM's growing interest in the rationalisation of its discourse by resorting to a form of quasi-empiricism, typical of the scientific discourse, which is already historically flawed from within. It started by analysing how a certain objective reality cannot operate except through its denial not only of 
another different, hence subjective reality, but also of its proper foundation as an ideal, self-evident truth already emanating from our SHE. In doing so, I had to draw on the historical as well as philosophical implications of what it is to be objective. The latter's subjectively-embodied nature led me to contend that while our desire for objectivity might be perceived as a fundamental impetus for our human quest for "meaning" and "order", subjectivity emerges as the primordial and ultimate ground upon which our virtually chaotic physical, metaphysical and ethical being may operate.

In other words, as we circulate, cherish and invest it in a spectacular extent with our human desires, fears and values (including rational academic thinking from the interpretive and the critical), objectivity may attain a quasi-absolute status. In this sense, objectivity turns out to be an exceptional form of subjectivity. It is the product of our desire for meaning/order or fear of irreferentiality/disorder. As a social construct, scientifically before it is socially conditioned, it should be bracketed or put under a Derridean erasure. The media discourse is, like all discourses, objective only when it fails to corroborate itself as the absolute factual truth of all theoretical as well as material circumstances, experimental or investigative, on the ground of unmediated reality. A good example of this is our present-day media discourse, which in its mass production, circulation and consumption by giant corporations, broad and narrow consumer audience, has made the postmodern social individual confined to a creedal dilemma of in which reality to believe. By bombarding the audience with positive-like data (with all its apparently verifiable and empirical journalistic factuality), on the one hand, and withholding it from others, on the other, by being omnipresent to the radical negation of the other realities, by granting life to certain events while acting as if the rest are inexistent, PMD plays the role of transcendence and quasi-absolutism.

Based on different eminent philosophers, social critics and also global events, I attempted to demonstrate that, while from a quasi-positivist vantage point, journalistic investigation may ascribe more credence to events on the ground, the fact that news gathering and broadcasting is mostly grounded upon the SHE of reporting from a real material terrain of events is, ironically, yet another grounding proof for its subjectivity rather than objectivity. The constant reiteration of news, entertainment and advertising content on accurately-planned schedules for their prime-time or 
day-time audiences through mass persuasion and propaganda is yet another form of mediated ritualism meant to indoctrinate as well as mobilise passive audiences. In a media-saturated age, where MSM's spatial and temporal omnipresence as well as prevalence as a believable narrative has increasingly been guaranteed by quasi-positive evidence, our current PMD could eventually be judged as a token for the quasi-absolutism of religious power. If bias has been part of the dominant news agencies (Associated Press, Reuters and AFP)'s neutrality towards international causes like, most notably, the Israeli-Palestinian question, then this may beg the following question: what kind of liberal democracies and ethics of freedom, which have for centuries been guaranteed by the freedom of the press as their Fourth Estate, are there in the West?

Moreover, if this has been the case for western MSM, then what horrors do our current Arab world's over-decayed MSM (backed up by its ruling tyrants and opportunists from businessmen, traditional intellectuals and politicians, even those of the allegedly-ousted regimes of the post-Arab Spring revolutions) still hold for their people? Perhaps, social media from the new media, in general, and social media, such as Facebook and Twitter, in particular, are striving to counter-balance, if not reverse, the whole MSM scene's discourse? Incidentally, giant media corporations, especially the world's current three dominant news agencies, are still being viewed as the ultimate providers of "objective" narratives to the mainstream audience, whose main interest remains to be only informed rather than weigh their knowledge against other different, perhaps, enlightening knowledge. One should also mention that not all alternative media magazines, journals or websites are at issue with propagandistic MSM. Many of them happen to corroborate official versions. In this respect, I encourage all scholars to firmly proceed with exposing the naked truth about the world's widely mediated masquerades. The difference between reality on the ground and the reported or mediated one is a significant issue at stake not only in this article but in the mediasphere as a whole; and no matter how mass media's sophistication has granted us virtual omnipresence on whatever ground of reality we wish ourselves as audience to experience, the lens(es) with which the reporter on the real material ground sees or wants to see (not to mention those of his/her employer and the audiences themselves) are what matters most. 
That the present PMD has increasingly paradoxically tended to conflate the positive and the transcendental in the hope of augmenting viewership ratings, it does not pose any problem to both critical and uncritical audience. Historically, cultural, artistic and scientific movements like the Renaissance Humanism (14 th $-16^{\text {th }}$ centuries) and the Enlightenment $\left(17^{\text {th }}\right.$ $19^{\text {th }}$ centuries) have had outstanding pivotal impacts not only on modern European civilization but on the birth of our modern human civilisation with all its techno-scientific sophistication and cultural complexity ${ }^{17}$. The philosophic and symbolic significance of these historic movements has been in their ability to have legitimised the theoretical (speculative and emancipatory narratives) as well as practical ground (techno-scientific and information revolutions) without which our considerably open PMD could not have emerged. From this very succinct historical foundation, I just wanted to remind readers and, above all, academic researchers, first, that human narratives on the legitimation of knowledge, as Lyotard elucidates in his The Postmodern Condition (1984), are what brought about outstanding scientific and material developments throughout human history, and techno-science has in turn led to the recent Information Revolution as an unprecedented glocal phenomenon.

In a complex world weighed down by numerous complex phenomena, all kinds of old barriers between the scientific and the non-scientific are meant to erode if we really liked to think up practical, effective (re)solutions to our problems. By contrast, the real menace I kept on warning against in this essay is the unprecedented union between the transcendental and the scientific to fully disseminate PMD. Ipso facto, if what MSM cover is licensed to exist objectively while what they do not is officially rebuked as subjective, then every objective reality, "as it takes its place on one side or the other" contends Debord, would have "no foundation apart from its transformation into its opposite: reality [which] erupts within the spectacle [of social lies]?" which is "real" (14) this time. Thus, in a world where nobody dares differentiate between what/who is real and what/who is illusory or what/who is right and what/who is wrong about unmediated reality, objective "truth" becomes "a moment of falsehood" (14) par excellence. In the realm of the symbolic production of meaning, in general, or in the mediated discursive reality, in particular, so long as the critical mind knows in whose hands concepts like objectivity (or 
its other side - subjectivity) are being manufactured, circulated and maintained, in society and does its best to counter that, no real threat or problem can be posed to human dignity.

Pertinent as well as intriguing questions could be raised with respect to our article, "Mainstream Media Discourse! Or the Divine Word of the Postmodern?" Indeed, they may read as follows: How far has our PMD substituted religious discourse? If so, how far could our MSM agents or TV presenters been regarded as media preachers? Could our MSM be labeled, "The Postmodern Holy Voice, par excellence"? Eventually, since objectivity as a concept has recently been turned increasingly into the pretext under which human and non-human rights may be objectively abused, then taking the same equal distance from both oppressor and oppressed, possessor and dispossessed and abuser and abused, just to enjoy the (post)modern fetish of being objective (especially, when intellectuals partake in taking advantage of it), I would argue, is the most radical, if not the ugliest, form of inhuman subjectivity. My point is that on no account should objectivity as a concept in social practice inhibit our effective activism as to central and complex rather than peripheral and superficial issues and conflicts, such as (apart from the ones mentioned earlier) climate change, world poverty, Human Rights abuse and secular or/versus non-secular fundamentalism. These are urgent questions which we cannot delay to tackle.

On no account should this analytical work be read as a naive diatribe or debasement waged against (state or private) MSM. In my view, it has always been up to MSM managers, investors and, above all, employees, from technical assistants to reporters, to decide about whether or not their media product should be faithful to the international manifesto of journalistic work, i.e. a minimum of what they call press neutrality, about which they keep on priding themselves; nor is it some sort of injustice done against investigative reporters worldwide, knowing that they are constantly jeopardising their lives for the sake of our access, as audience, to truth. Whatever category to which the reporter may belong, still s/he can do justice to their own vocation's integrity by simply depicting what is going on upon the ground of reality instead of hiding or distorting a large amount of it. Furthermore, MSM's often opportunistic discourse should not in any way be dismissive of alternative media, which have usually been 
discordant with the former's mainstream or prevailing tendencies to indoctrinate, mobilize and maintain their supreme appeal to the masses. With all my due respect to their resistance to MSM, alternative media (print or electronic, audio or visual, public, local, street or virtual) should not be taken for granted as entirely faithful to their people's sovereignty or events occurring on the real ground. At times, popular arts or outlets too may, ironically, have their proper ways to take sides with the wrong ideological camp or for material profit, which renders any endeavour at postmodern objectivity nearly arbitrary. My attention was, therefore, directed to those quasi-absolutist tendencies (lucrative, elitist or ideological) which tend to submerge the remainder of the postmodern social individual's free will, as a decent citizen, to differentiate between who/what is right and who/what is wrong about the reality of the world.

\section{References}

Abu Nimah, H. (2009). "Covering up Israel's Gaza Crimes with UN Help.” The Electronic Intifada. 12 May 2009. Web. 12 Oct. 2015. $<$ https://electronicintifada.net/content/covering-israels-gaza-crimes-unhelp/8226>

Aloni, U. (2010). "Judith Butler: As a Jew, I Was Taught It Was Ethically Imperative to Speak Up." Haaret:. Web. 24 Feb.2010. <http://www.haaretz.com/news/judith-butler-as-a-jew-i-was-taught-itwas-ethically-imperative-to-speak-up-1.266243

$<$ http://www.haaretz.com/news/judith-butler-as-a-jew-i-was-taught-itwas-ethically-imperative-to-speak-up-1.266243>

Amnesty International. "USA: Stop Arms Transfers to Israel Amid Growing Evidence of War Crimes in Gaza." Web. 31 Jul. 2014. $<$ https://www.amnesty.org/en/latest/news/2014/07/usa-stop-armstransfers-israel-amid-growing-evidence-war-crimes-gaza/>

Baudrillard, J. (1994). Simulacra and Simulation. Trans. Sheila Faria Glaser. Michigan: U of Michigan Press. Print.

Bourdieu, P. (1998). On Television. Trans. Priscilla Parkhurst Ferguson. NY: NY Press. Print.

“Charlie Hebdo Attack: Three Days of Terror.” BBC.com. Web. 07 Jan. 2015. $<$ http://www.bbc.com/news/world-europe-30708237>

Chomsky, N. (2002). Media Control: The Spectacular Achievements of Propaganda (2nd edition). NY: Open Media. Print.

Chomsky, N. (2014). Chomsky, Noam. Power Systems: Conversations with David 
Barsamian on Global Democratic Uprisings and The new Challenges to US Empire. London: Penguin Books. Print.

Coronel, S. (2014). "Is It Really Investigative Reporting's Golden Age? Global Investigative Journalism Network. 21 Oct. 2014. Web. 02 Oct. 2015. <http://gijn.org/2014/10/21/is-it-really-investigative-reportings-goldenage $/>$

Corwin, P. (2011). "Foreword." The Srebrenica Massacre: Evidence, Context, Politics. Ed. Edward S. Herman. Creative Commons Attribution, 2011. Web. 02 Oct. 2015. <http://resistir.info/livros/srebrenica_ massacre_rev_3.pdf>

Cranford, N. (2015). "Difference Between Positivist, Interpretive and Critical Sociology." Demand Media. Seattlepi. Web. 10 Jun. 2015. < http://education. seattlepi.com/difference-between-positivist-interpretive-critical-sociology6396.htm $>1$

Dallaire, R. (2007). "The Media Dichotomy." The Media and the Rwanda Genocide. Ed. Allan Thompson. London: Pluto Press. Print.

Debord, G. (2006). The Society of the Spectacle. Trans. Donald Nicholson-Smith. NY: Zone Books. Print.

Erickson, B. (2015). "How The NY Times Hides the Scandal of US-Israeli War Crimes.” TimesWarp. Web. 21 Sep. 2015. http://timeswarp.org/2015/09/21/ how-the-ny-times-hides-the-scandal-of-us-israeli-war-crimes />

Foucault, M. (2002). The Archaeology of Knowledge. Trans. A. M. S. Smith. London: Routledge Classics. Print.

Friedman, M. (2014). "What the Media Gets Wrong About Israel." The Atlantic. Web. 30 Nov. 2014. <http://www.theatlantic.com/international/ archive/2014/11/how-the-media-makes-the-israel-story/383262/>

Gonzalez-Mena, J., et al. (2010). "The Media as an Influence on Socialization." Education.com. Web. 20 Jul. 2010. <http://www.education.com/ reference/article/media-as-influence-socialization/>

Hassan, R. (2004). Media, Politics and the Network Society. NY: Open UP. Print. Hartley, J. (2002). "Mediasphere". Communication, Cultural and Media Studies: The Key Concepts ( $3 \mathrm{rd}$. ed.).London: Routledge.

Herman, Edward. S., and Noam Chomsky. (1988). Manufacturing Consent: The Political Economy of the Mass media. NY: Pantheon Books. Print.

History.<http://www.history.com/\#>

Hussain, E. and M. Jahanzaib. (2015). "Genocide of Muslims in Myanmar."

Daily Times Pakistan. Web. 06 Jun. 2015. <http://www.dailytimes.com.pk/ Columnist/dr-ejaz-hussain-and-muhammad-jahanzaib>

Husserl, E. (2008). Historical Dictionary of Existentialism. Ed. Stephen 
HSS, vol. V, no. 2 (2016): 40-73

Michelman. Toronto: The Scarecrow Press. Print.

"ISIS Sex Atrocities: Child rape, Forced Virginity Surgeries Exposed in UN Report."

Russia Today. Web. 09 May 2015. <https://www.rt.com/news/257085-isissexual-abuse-un/>

"Journalistic Objectivity." Pediaview: Open Source Encyclopedia. Web. 01 Oct.

2015.<https://pediaview.com/openpedia/Journalistic_objectivity $>$

Kamalipour, Y. R., and Nancy Snow, eds. (2004). War, Media and Propaganda: A Global Perspective. NY: Rowman and Littlefield Publishers. Print. 2015.

$<$ https://www.kon.org/urc/v8/groat.html>

Katz, J. M. (2015). “In Chapel Hill, Suspect's Rage Went Beyond a Parking

Dispute." The New York Times. Web. 03 Mar. 2015. < http://www.nytimes.com /2015/03/04/us/chapel-hill-muslim-student-shootings-north-carolina. html?_r $=0>$

Laville, S. (2015). "UN Aid Worker Suspended for Leaking Report on Child Abuse by French Troops." The Guardian. Web. 29 Apr. 2015. <http://www.theguardian.com/world/2015/apr/29/un-aid-workersuspended-leaking-report-child-abuse-french-troops-car>

Lyotard, J.-F. (1984). The Postmodern Condition: A Report on Knowledge. Trans. Bennington and Brian Massumi. Manchester: Manchester UP. Print.

Machin, D. and T. Van Leeuwen. (2007). Global Media Discourse: A Critical Introduction. London: Routledge. Print.

McKibben, B. (2006). The Age of Missing Information. NY: Random House, 2006. Print.

Merleau-Ponty, M. (2005). Phenomenology of Perception. Trans. Colin Smith. London: Routledge. Print.

Moran, J. (2002). Interdisciplinarity. London: Routledge. Print.

Murphy, E. (2010). "Perceptions of the International Media in Post-Conflict Srebrenica, Bosnia-Herzegovina." Independent Study Project (ISP) Collection, (2010): 1-39. Web. < http://digitalcollections.sit.edu/isp_collection/862/>

"Objective." Oxford Advanced Learner's Dictionary (New 8th edition): International Student's Edition. Oxford: Oxford UP., 2010. Print.

Ore, J. (2015). "Royal Baby Birth Heralded by Politicians, Fans and Brands on Social Media." CBS News. Web. 02 May 2015. < http://www. $\mathrm{cbc} . c a /$ news/trending/royal-baby-birth-heralded-by-politicians-fans-andbrands-on-social-media-1.3058823>

Popper, K. (1957). The Poverty of Historicism. Boston: Beacon Press. Print.

Popper, K. (1962). Conjectures and Refutations. London: Basic Books, 1962. Print. 
Popper, K. (2005). The Logic of Scientific Discovery. London: Routledge. Print.

Robertson, R. (1995). "Glocalization: Time-Space and HomogeneityHeterogeneity."

Global Modernities. Eds. Mike Featherstone, Scott Lash, and Roland Robertson. London: Sage Publications. 25-44. Print.

Shelmon, C. (2013). Framed: How Colin Powell's U.N. Speech on Iraq Set the News Agenda for American and British Television News. MA. Maryland: Maryland U.P., 2013. Web. 27 May 2015. <http://drum.lib.umd.edu/bitstream/ handle/1903/14264/Shlemon_umd_0117N_14025.pdf?sequence=1\&isAllo wed $=\mathrm{y}>$

Shermer, M. (2007). "The Really Hard Science." Scientific American. 12 Sep. 2007.

Web 02 Oct. 2015. < http://www.scientificamerican.com/article/the-reallyhard-science/>

Spivak, G. C. (1997). "Preface.” Of Grammatology (corrected edition). By Jacques

Derrida. Baltimore: The Johns Hopkins UP. Print.

“The Big Four." New Internationalist Magazine, 100 (June, 1981), n.a. Web. 03 Jun. 2015. <http://newint.org/features/1981/06/01/four/>

“The Rwandan Genocide." History. Web. 05 Oct. 2015.

$<$ http://www.history.com/topics/rwandan-genocide>

Turow, J. (2009). Media Today: An Introduction to Mass Communication (3ed ed.). NY: Routledge, 2009: 56. Print.

Warren, M. (2012). "Interpretive and Critical Research: Methodological Blasphemy!" African Journal of Business Management 6.1, (January, 2012): 1-6.

Žižek, S. (2012). Less Than Nothing: Hegel and the Shadow of Dialectical Materialism. London: Verso. Print.

"19th Century Scientific Historiography." Philosophy of History. The Internet Encyclopedia of History. Web. 02 Oct.2015. http://www.iep.utm.edu/history/

${ }^{1}$ Discourse here should be understood, in its narrow sense, in J-F Lyotard's terms as a "meta-narrative" legitimating certain "truth" (The Postmodern Condition 31-38). In its broader sense, however, it should be grasped as socio-political "practices obeying certain rules,"(155) to use Michel Foucault's words, i.e., by looking for how such media practices from preparation to production and delivery of narratives are emanating from as well as structuring of the "ordering of [certain] objects" (The Archaeology of Knowledge 54) or practices in reality.

${ }^{2}$ Ex-act is a concept which I will elucidate in the dialectics of objectivity. In it I play on two meanings ("exact", i.e., precision of and "exterior act", viz., of 
examination to define an allegedly homogeneous body of knowledge or truth without influencing it). In this sense, to define objectivity, one has to proceed from outside objective reality.

3 " $19^{\text {th }}$ Century Scientific Historiography." Philosophy of History. The Internet Encyclopedia of Philosophy. Web. 02 Oct. 2015.<http://www.iep.utm.edu/ history/>

${ }^{4}$ As such, it has been reformulated by Gayatri Chakravorty Spivak in her preface to the corrected edition of the French philosopher Jacques Derrida's Of Grammatology (1997). Spivak, G. C: 1997: xiv.

${ }^{5}$ In scientific terms, this meant the rejection of any form of relativism. See Husserl, 2008: 183-87.

${ }^{6}$ The mediasphere is a term coined by the British Professor of Cultural Science and Media Studies John Hartley along with Australian Professor of sexualised media Alan McKee in 1996. It designates "a smaller 'sphere' within the semiosphere [or the cultural universe of a given culture], and includes all the output of the mass media, both fictional and factual. The mediasphere, in turn, encloses the public sphere, and the 'public sphericules' that seem to have proliferated within it. The idea is that the public sphere is not separate from but enclosed within a wider sphere of cultural meaning, which is itself mediated as it is communicated back and forth from the cultural to the public domain." See Hartley, 2002: 142.

7 Amnesty International. "USA: Stop arms transfers to Israel amid growing evidence of war crimes in Gaza." Web. 31 Jul. 2014. $<$ https://www.amnesty.org/en/latest/news/2014/07/usa-stop-arms-transfersisrael-amid-growing-evidence-war-crimes-gaza/>

${ }^{8}$ In her interview with Udi Aloni, a reporter of the Israeli journal Haarets, the Jewish philosopher and social theorist Judith Butler contends that "The Israeli government and the media started to say that everyone who was killed or injured in Gaza was a member of Hamas; or that they were all being used as part of the war effort; that even the children were instruments of the war effort; that the Palestinians put them out there, in the targets, to show that Israelis would kill children, and this was actually part of a war effort. At this point, every single living being who is Palestinian becomes a war instrument. They are all, in their being, or by virtue of being Palestinian, declaring war on Israel or seeking the destruction of the Israel. So any and all Palestinian lives that are killed or injured are understood no longer to be lives, no longer understood to be living, no longer understood even to be human in a recognizable sense, but they are artillery." (Aldoni, 2010).

9 "The Rwandan Genocide." History. Web. 05 Oct. 20015.<http://www.history. 
HSS, vol. V, no. 2 (2016): 40-73

com/topics/rwandan-genocide>

${ }^{10}$ Ibid.

11 "a retired Lieutenant-General. He led the United Nations Assistance Mission for Rwanda (UNAMIR) to help implement the Arusha accords. He is the author of Shake Hands with the Devil: The Failure of Humanity in Rwanda and now sits in the Senate of Canada as a member of the Liberal party". Dallaire, Roméo. "The Media Dichotomy." The Media and the Rwanda Genocide. Ed. Allan Thompson. (London: Pluto Press, 2007): 12-19.

12 "The Big Four." New Internationalist Magazine, 100 (June, 1981), n.a. Web. 03 Jun. 2015. <http://newint.org/features/1981/06/01/four/>

13 "Journalistic Objectivity." Pediaview: Open Source Encyclopedia. Web. 01 Oct. 2015.<https://pediaview.com/openpedia/Journalistic_objectivity>

${ }^{14}$ See: "Journalistic objectivity" in Pediaview.

15 "Charlie Hebdo Attack: Three Days of Terror." BBC.com. Web. 07 Jan. 2015. <http://www.bbc.com/news/world-europe-30708237>

16 "ISIS Sex Atrocities: Child rape, Forced Virginity Surgeries Exposed in UN Report." Russia Today. Web. 09 May 2015. <https://www.rt.com/news/257085isis-sexual-abuse-un/ $>$

${ }^{1}$ History. $<$ http://www.history.com/\#>

\section{Biographical note}

Yasser Rhimi is currently a $\mathrm{PhD}$ Scholar at the University of Manouba, Tunisia, and a Lecturer of Anglo-American Literature and Culture Studies at the University of Tunis, Tunisia. He has a major in Literature and a minor in Cultural Studies. He has a number of analytical papers approaching discourse, power and truth in media, politics, culture, and environment. His current interests are chiefly in Interdisciplinary Humanities, Ecological Criticism, Media Studies and International Politics. He also has an interest in creative writing, particularly, in poetry. 